\title{
ETIKA BISNIS ISLAM DALAM MANAJEMEN BISNIS KULINER
}

\author{
Inayah Swasti Ratih ${ }^{1}$ \\ Zainur Ridho ${ }^{2}$ \\ Siti Aisyah ${ }^{3}$ \\ 1,3 Islamic Business Management, Sekolah Tinggi Ekonomi dan Bisnis Islam Badri Mashduqi \\ ${ }^{2}$ Hajj and Umrah Management, Sekolah Tinggi Ekonomi dan Bisnis Islam Badri Mashduqi \\ Email: inayahswastiratih@stebibama.ac.id ${ }^{1}$; zainurridho@stebibama.ac.id²; sitiaisyah@stebibama.ac.id ${ }^{3}$
}

\begin{abstract}
Introduction: The purpose of this research is to explain how the application of Islamic business ethics in the management of culinary business. Culinary business is a business that is widely pursued by the community because it is easy and needed by the market, but there are still many business people who heed islamic business ethics in their business management. Whereas business ethics is an important element of business management itself. Then there needs to be guidelines for businesses to apply Islamic business ethics into the management of culinary business.

Methods: This research uses qualitative research with literature study method.

Results: Islamic business ethics principles will be able to help culinary business management more targeted and have clear values both in the world and in the hereafter. These principles are 1) Tauhid, 2) Worship, 3) Amanah, 4) Hikmah, 5) Adil, 6) Ihsan, 7) Please help, 8) Halalan Thayyiban and 9) Deliberation. Because binsis activities not only to gain profit but to carry out the commandments of Allah SWT.

Conclusion and suggestion: The principle of Islamic business ethics must be done in every business activity because it will be able to increase the productivity of the business. This research is only theoretical,so there needs to be further research that is empirical.
\end{abstract}

Keywords: Islamic Business Ethics, Business Management, Culinary Business

\section{PENDAHULUAN}

Keberadaan manusia di bumi bukanlah semata-mata tidak memiliki tujuan, Sang Pencipta memiliki tujuan dimana sudah jelas tertulis dalam Al Quran Surat At Thalaq ayat 12 yang menyatakan bahwa Allah-lah yang menciptakan tujuh langit dan seperti itu pula bumi, perintah Allah berlaku pada manusia agar manusia mengetahui bahwasanya Allah Maha Kuasa atas segala sesuatu dan sesungguhnya ilmu Allah benar-benar meliputi segala sesuatu. Begitu juga pada Quran Surat Adzariyat ayat 56 dimana di nyatakan bahwa Allah menciptakan jin dan manusia hanya supaya untuk menyembah Allah. Oleh karena itu setiap kegiatan manusia di muka bumi ini tidak boleh terlepas dari perintah-perintah 
dan aturan agama Islam yang telah ditetaokan, hal tersebut dilakukan untuk memenuhi tujuan diciptakannya manusia.

Begitu juga dalam kegiatan pemenuhan kebutuhan manusia, terdapat banyak cara, baik dengan bekerja sebagai karyawan maupun mencari rejeki dengan berdagang atau berbisnis. Keduanya diperbolehkan oleh Agama Islam dengan ketentuan-ketentuan yang telah ditetapkan seperti harus Halal dan Toyyib. Berbisnis juga telah dicontohkan oleh Rasulullah, dimana beliau sejak berusia 12 tahun telah diajak pamannya berdagang ke Syiria, hingga ilmu berdagang sdah dipelajarinya sejak saat itu. Dengan bermodalkan pengalaman serta praktik langsung, Rasulullah memulai bisnis dagangnya dengan penuh dedikasi dan keuletan, didukung dengan sifat fathanah dan siddiq yang dimilikinya mampu membuat bisnisnya berkembang pesat dan menjadikan dirinya sebagai seorang pebisnis yang jujur dan terpercaya. Hal ini patut dijadikan contoh dalam bisnis yang berkembang sekarang.

Saat ini binsis yang cukup mudah dilakukan oleh kebanyakan orang dimana tidak perlu membutuhkan banyak modal adalah bisnis yang bergerak dibidang kuliner. Selain itu pangsa pasar dalam bisnis kuliner ini mampu menembus semua kalangan baik yang masih anak-anak maupun yang sudah dewasa, baik di dalam negeri maupun luar negeri dan bagi masyarakat ekonomi menengah ke bawah hingga menengah keatas. Melalui berbagai cara dan inovasi baik dalam produksinya maupun dalam membangun branding hingga pemasarannya bisnis kuliner menjadi pilihan pertama bagi pengembang bisnis. Hal ini juga didukung dengan pertumbuhan sektor industri makanan triwulan 1 tahun 2017 berada pada urutan kedua dari pertumbuhan sector industry di Indonesia yakni sebesar $8,15 \%$.

Oleh karena itu, bisnis kuliner ini cukup menjanjikan jika dilakukan dengan konsisten, namun perlu diperhatikan berbisnis dalam Islam tak semata-mata hanya untuk mendapatkan keuntungan untuk diri sendiri karena berbisnis tidak hanya melibatkan satu orang saja atau produsen saja namun juga mencakup banyak pihak, maka Islam mengatur hal tersebut agar terciptanya keadilan diantara pihak-pihak yang terlibat. Pengaturan tersebut di atur dalam prinsip-prinsip dalam Islam yakni prinsip kebebasan terikat dimana mencakup kebebasan berdasarkan keadilan, undang-undang, agama dan etika. Adanya hal-hal yang membatasi dalam kebebasan terikat ini merupakan sebuah etika bisnis Islam yang didalamnya didasarkan pada keadilan. Tujuan penelitian ini adalah menjelaskan mengenai penerapan etika bisnis Islam yang merupakan salah satu unsur dalam manajemen bisnis Islam, dimana nantinya akan diterapkan baik dari kegiatan perencanaan, pengelolaan, hingga evaluasinya agar pecapaian tujuan bisnis Islam yang tidak semata-mata hanya mencari keuntungan namun menjalankan kewajiban sebagai seorang muslim bisa tercapai. 


\section{KAJIAN PUSTAKA}

\section{Etika Bisnis Islam}

\section{A. Pengertian}

Istilah etika berasal dari bahasa Yunani ethos yang memiliki arti adat kebiasaan. Dalam pengertian ini etika berkaitan dengan kebiasaan hidup yang baik, baik itu berhubungan dengan diri sendiri maupun berhubungan dengan orang lain. ${ }^{1}$ Dalam KBBI, etika berarti ilmu mengenai apa yang baik dan apa yang buruk, kumpulan nilai yang berkenaan dengan akhlaq serta asas perilaku yang menjadi pedoman. ${ }^{2}$

Secara terminologi, etika dapat diartikan sebagai studi sistematis mengenai konsep nilai, baik, buruk, benar, salah yang memimpin manusia dalam membuat keputusan serta bertingkah laku. ${ }^{3}$ Etika bisnis merupakan cara untuk melakukan kegiatan bisnis, yang mencakup seluruh aspek yang berkaitan dengan individu, perusahaan dan juga masyarakat. Etika bisnis merupakan salah satu bagian dari dunia bisnis juga banyak diterangkan dalam Al Quran, pendek kata Qur'an merupakan sumber utama umat Islam khususnya, dan manusia pada umumnya dalam menjalankan bisnis Islam. ${ }^{4}$

Etika deontologis memandang jika etika merupakan hal yang tetap dengan kata lain tindakan apapun baik benar ataupun salah adalah karena adanya sifat dasar yang melekat, sementara etika konsekuensialis merupakan kebenaran tindakan apapun tergantung pada konsekuensinya daripada sifat intrinsiknya, sehingga tindakan terntentu bisa benar dalam konteks tertentu dan dalam konteks lain berdasarkan konsekuensinya. ${ }^{5} \mathrm{Hal}$ ini menunjukan bahwa etika bisnis islam menunjukan bahwa memiliki prinsip dasar yang selalu tetap yakni harus sesuai dengan perintah Allah Subhanahu Wa Ta'ala.

Dalam pandangan Islam khususnya ekonomi Islam, bisnis dan etika tidak harus dipandang sebagai dua hal yang saling bertentangan. Bisnis merupakan simbol dari urusan duniawi namun juga dianggap sebagai bagian integral dari halhal yang bersifat investasi akhirat. Artinya, jika orientasi bisnis dan upaya investasi akhirat (diniatkan sebagai ibadah dan merupakan totalitas kepatuhan kepada Tuhan), maka bisnis dengan sendirinya harus sejalan dengan kaidahkaidah moral yang berlandaskan keimanan kepada akhirat. Bahkan dalam Islam, pengertian bisnis itu sendiri tidak dibatasi urusan dunia, tetapi mencakup pula

\footnotetext{
${ }^{1}$ Buchari Alma dan Donni junni Priansa. 2009. Manajemen Bisnis Syariah. Bandung: Alfabeta. h. 95

2 Departemen Pendidikan Nasional. 2008. Kamus Besar Bahasa Indonesia, Jakarta: Pusat Bahasa. h. 105

${ }^{3}$ Faisal Badroen. 2006. Etika Bisnis dalam Islam. Jakarta: Kencana, Cetakan ke-2. h. 30

${ }^{4}$ Arifin Jonan. 2009. Etika Bisnis Islam. Semarang: Wali Songo Press. h. 75

5 Jonsson, P.0. 2011. On Utilitarianism vs virtue ethics as foundations of economic choice theory. Humanocomics. Vol 27 No. 1, h. 24-40.
} 
seluruh kegiatan kita di dunia yang "dibisniskan" (diniatkan sebagi ibadah) untuk meraih keuntungan atau pahala akhirat. ${ }^{6}$

Mustaq Ahmad menyatakan didalam buku Etika Bisnis dalam Islam tentang konsep bisnis menurut ketegori yakni bisnis yang menguntungkan, bisnis yang merugi dan selanjutnya tentang pemeliharaan prestasi. Disamping adanya hadiah dan hukuman yang dijanjikan. Bisnis yang benar-benar sukses menurut Al Quran adalah bisnis yang dapat membawa keuntungan pada pelakunya dalam dua fase kehidupan yang fana dan terbatas yakni akhirat (Mustaq 2001). ${ }^{7}$

Dari pengertian-pengertian di atas dapat dipahami bahwa etika bisnis Islam adalah sebuah kegiatan dalam kegiatan perdagangan baik jasa maupun dagang yang dilakukan tidak hanya untuk mencari keuntungan tapi sebagai bentuk kegiatan ibadah yakni mencari rezeki dimana hasilnya tidak hanya akan dirasakan di dunia namun juga di kehidupan setelah dunia yaitu akhirat, dengan cara selalu melaksanakan kegiatan bisnisnya sesuai dengan ketentuan agama Islam yang dituliskan dalam Al Qur'an dan Hadits.

\section{B. Prinsip-prinsip}

Ahmad dalam bukuya Johan Arifin yang berjudul "Etika Bisnis Islami" memberikan petunjuk sebagai faktor dilaksanakannya prinsip benevolence (ihsan), diantaranya kemurahan hati (leniency), motif pelayanan (service motives) dan kesadaran adanya Allah SWT dan aturan-aturan yang berkaitan pelaksaaan yang menjadi prioritas (consciousness of Allah and of His prescribed priorities).

Prinsip-prinsip etika bisnis menurut Al-Qur'an adalah:

1. Melarang bisnis yang dilakukandengan proses kebatilan (QS. 4:29).

2. Bisnis harus di dasari kerelaan dan keterbukaan antara keduabelah pihak dan tanpa ada pihak yang dirugikan. Orang yang berbuat batil termasuk perbuatan aniaya, melanggar hak dan berdosa besar (QS.4:30). Sedangkan orang yang menghindarinyaakan selamat dan mendapat kemuliaan (QS.4:31).

3. Tidak boleh mengandung unsur riba (QS. 2:275).

4. Kegiatan bisnis juga memilikifungsi sosial baik melalui zakat dan sedekah (QS.9:34). Pengembangan harta tidak akan terwujud kecuali melalui interaksi antar sesama dalamberbagai bentuknya.

5. Melarang pengurangan hak atas suatu barang atau komoditasyang didapat atau diproses dengan media takaranatau timbangan karena merupakan bentuk kezaliman (QS. 11:85), sehingga dalam praktek bisnis, timbangan harus disempurnakan (QS. 7:85, QS. 2:205).

${ }^{6}$ Abdul Aziz. 2013. Etika Bisnis Perspektif Islam. Bandung: Alfabeta. h. 56

${ }^{7}$ Ahmad Mustaq. 2001. Etika Bisnis dalam Islam. Jakarta: Pustaka Al Kautsar. h. 80 
6. Menjunjung tinggi nilai-nilaikeseimbangan baik ekonomi maupun sosial, keselamatan dan kebaikan serta tidak menyetujuikerusakan dan ketidakadilan.

7. Pelaku bisnis dilarang berbuat zalim (curang) baik bagidirinya sendiri maupun kepada pelaku bisnis yanglain (QS. 7:85, QS.2:205).

Berikut beberapa panduan etika dalam bisnis / usaha yang telah dicontohkan oleh Nabi Muammad Saw ${ }^{8}$ :

1. Kejujuran. Kejujuran adalah syarat yang paling mendasar dalam kegiatan bisnis. Dalam tataran ini, beliau bersabda "Tidak dibenarkan seorang muslim menjual satu jualan yang mempunyai aib, kecuali ia menjelaskan aibnya," (H.R. AlQuzwani). "Siapa yang menipu kami, maka dia bukan kelompok kami" (H.R. Muslim). Rasulullah sendiri adalah contoh perilaku yang selalu bersikap jujur dalam berbisnis. Beliau melarang para pedagang meletakkan barang busuk di sebelah bawah dan barang baru di bagian atas. Kejujuran yang diterapkan oleh rasulullah ini adalah sebagai perwujudan dari prinsip custumer oriented pada konteks sekarang, yaitu prinsip bisnis yang selalu menjaga kepuasan pelanggan. ${ }^{9}$

Dampak dari prinsip yang diterapkan oleh rasulullah SAW ini, para pelanggan Rasulullah SAW tidak pernah merasa dirugikan serta tidak ada keluhan tentang janjijanji yang diucapkan, karena barangbarang yang Disepakati dalam kontrak tidak ada yang dimanipulasi atau dikurangi. ${ }^{10}$ Dengan customer oriented memberikan ruang pilihan kepada para konsumen atas hak khiyar (meneruskan atau membatalkan transaksi) jika terjadi indikasi penipuan atau konsumen merasa dirugikan ${ }^{11}$. Konsep Khiyar ini dapat menjadi faktor dalam menguatkan posisi konsumen di mata produsen, sehingga tidak terjadi perbuatan semena-mena oleh produsen terhadap pelanggannya.

2. Menolong atau memberi manfaat kepada orang lain, kesadaran tentang signifikansi sosial kegiatan bisnis. Dalam Islam pelaku bisnis itu tidak hanya sekedar mengejar keuntungan semata, seperti yang diajarkan dalam Ekonomi Kapitalis, tetapi juga berorientasi kepada sikap ta'awun (menolong orang lain) sebagai implikasi sosial kegiatan bisnis.

3. Tidak boleh menipu. Ukuran takaran dan timbangan harus benar. Firman Allah: "Celakalah bagi orang yang curang, yaitu orang yang apabila menerima takaran dari orang lain, mereka minta dipenuhi, dan apabila mereka menakar atau menimbang untuk orang lain, mereka mengurangi" (QS 83:112). Seorang

\footnotetext{
${ }^{8}$ Aris Baidowi. 2011. Etika Bisnis Perspektif Islam. Jurnal Hukum Islam. Volume 9 Nomor 3. h. 1829

${ }^{9}$ Afzalur Rahman. 1995. Doktrin ekonomi Islam jilid I. Yogyakarta: Dana Bhakti Wakaf

10 Norva Dewi. 2015. Bisnis Dalam Perspektif Islam (Telaah Konsep, prinsip dan Landasan Normatif). Al Tijary, Vol. 01 No. 01

11 Muslich. 2010. Etika Bisnis Islami. Yogyakarta: Ekonisia Fakultas Ekonomi UII
} 
pengusaha atau produsen dituntut untuk memiliki sifat transparan. Transparansi terhadap kosumen ini adalah ketika seorang produsen mampu berlaku terbuka terhadap mutu, kuantitas, komposisi dan lainnya.

4. Tidak boleh menjelekkan bisnis orang lain, agar orang membeli kepadanya. Nabi Muhammad SAW bersabda, "Janganlah seseorang di antara kalian menjual dengan maksud untuk menjelekkan apa yang dijual oleh orang lain," (H.R. Muttafaq 'alaih). Islam menghargai persaingan dalam bisnis, namun haruslah persaingan yang tidak menghalalkan segala cara, karena hal itu bertentangan dengan prinsip-prinsip muamalah dalam Islam. Islam menyerukan pemeluknya agar senantiasa berlomba-lomba dalam kebaikan, bukan saling menjatuhkan. Rasululllah SAW telah memberikan contoh bagaimana bersaing dengan baik dan melarang persaingan yang tidak sehat. Sebagaimana disebutkan dalam QS. Al Baqarah ayat 188: Dan janganlah sebahagian kamu memakan harta sebahagian yang lain di antara kamu dengan jalan yang batil dan (janganlah) kamu membawa (urusan) harta itu kepada hakim, supaya kamu dapat memakan sebahagian daripada harta benda orang lain itu dengan (jalan berbuat) dosa, padahal kamu mengetahui.

5. Tidak menimbun barang. Dalam Islam istilah ini disebut dengan Ihtikar. Ihtikar ialah menimbun barang (menumpuk dan menyimpan barang dalam masa tertentu, dengan tujuan agar harganya suatu saat menja di naik dan keuntungan besar pun diperoleh). Perbuatan ini sangat dilarang keras oleh Rasulullah.

6. Tidak melakukan monopoli. Monopoli sangat dilarang dalam Islam. Islam tidak membenarkan eksploitasi (penguasaan) individu tertentu atas hak milik sosial, seperti air, udara, dan tanah serta kandungan isinya seperti barang tambang dan mineral.

7. Menjual hanya komoditas bisnis yang halal bukan barang yang haram, seperti babi, anjing, minuman keras, ekstasi, dan sebagainya. Nabi Muhammad saw bersabda, "Sesungguhnya Allah mengharamkan bisnis miras, bangkai, babi dan patungpatung," (H.R. Jabir). Dalam konteks kekinian, umat Islam juga sering terjebak tidak minuman keras dan babi. Dua jenis produk ini memang tidak secara eksplisit menjadi konsumsi atau dagangan Muslim, namun produk turunan dari dua produk ini banyak beredar dan bahkan diperdagangnkan oleh muslem.

8. Bisnis harus terbebas dari unsur riba. Firman Allah, "Hai orang-orang yang beriman, tinggalkanlah sisa-sisa riba jika kamu beriman," (QS.al- Baqarah: 278). Pelaku dan pemakan riba dinilai Allah sebagai orang yang kesetanan (QS. 2: 275). Oleh karena itu, Allah dan RasulNya mengumumkan perang terhadap riba.

9. Bisnis dilakukan dengan suka rela, tanpa paksaan. Firman Allah, "Hai orang-orang yang beriman, janganlah kamu saling memakan harta sesamamu dengan cara yang batil, kecuali dengan jalan bisnis yang berlaku dengan suka-sama suka di antara kamu," (QS. 4: 29). 
10. Membayar upah sebelum kering keringat karyawan. Nabi Muhammad saw bersabda, "Berikanlah upah kepada karyawan, sebelum kering keringatnya." Hadist ini mengindikasikan bahwa pembayaran upah harus disegerakan dan tidak boleh ditunda-tunda. Selain itu termasuk salah satu dari kewajiban pengusaha adalah memberikan upah yang adil bagi karyawan, tidak melakukan ekploitasi dan menjaga hak-hak karyawan.

\section{Manajemen Bisnis Kuliner}

\section{A. Pengertian}

Ricky W. Griffin mendefinisikan manajemen sebagai sebuah proses perencanaan pengorganisasian, pengkoordinasian dan pengontrolan sumber daya untuk mencapai sasaran (goals) secara efektif dan efesien. Efektif berarti tujuan dapat dicapai sesuai dengan perencanaan, sedangkan efisien berarti tugas yang ada dilaksanakan secara benar, terorganisasi sesuai dengan jadwal. ${ }^{12}$

Menurut James A.F. Stoner yang dikutip oleh subandi manajemen adalah suatu proses perencanaan, pengorganisasian, kepemimpinan dan pengendalian upaya anggota organisasi dan menggunakan semua sumber daya organisasi untuk mencapai tujuan yang telah ditetapkan. ${ }^{13}$

Menurut S. Mahmud Al-Hawary manajemen (Al-Idarah) manajemen adalah mengetahui kemana yang dituju, kesukaran apa yang harus dihindari, kekuatankekuatan apa yang dijalankan, dan bagaimana mengemudikan kapal anda serta anggota dengan sebaik-baiknya tanpa pemborosan waktu dalam proses mengerjakannya. Dari ta'rif di atas memberi gambaran bahwa manajemen merupakan kegiatan, proses dan prosedur tertentu untuk mencapai tujuan akhir secara maksimal dengan bekerja sama sesuai jobnya masing-masing. Maka kebersamaan dan tujuan akhirlah yang menjadi fokus utama. ${ }^{14}$

Menurut Kamus Besar Bahasa Indonesia (Tim Penyusun Kamus, 2007: 90) Bisnis adalah usaha komersial dalam dunia perdagangan, bidang usaha, atau usaha dagang. Sejalan dengan itu bisnis dalam kamus bahasa Inggris-Indonesia business berarti "perusahaan, urusan, atau usaha. ${ }^{15}$ Bisnis (perusahaan) adalah organisasi yang menyediakan barang atau jasa untuk dijual dengan maksud mendapatkan laba. 16

Kuliner sendiri memiliki arti makanan. Maka manajemen bisnis kuliner merupakan perencanaan, pengorganisasian, dan pengendalian upaya organisasi

\footnotetext{
12 Undang Ahmad Kamaludin dan Muhammad Alfan. 2010. Etika Manajemen Islam. Jakarta: Pustaka Setia. h. 27

${ }^{13}$ Agus Sabardi. tt. Manajemen Pengantar. Edisi Revisi, Yogyakarta,UPP AMP YKN. h. 5

${ }^{14}$ Ek. Mochtar Effendy. 1986. Manajemen: Suatu Pendekatan Berdasarkan Ajaran Islam. Jakarta: Bharata Karya Aksara.

15 T.R.R Kamus Bebar Bahasa Indonesia, Op. cit., h. 105

16 Ronald J ebert dan Ricky W. Griffin. 2006. Bisnis. Alih Bahasa Rd. Soemarnagara. Jakarta: Erlangga. h. 4
} 
sebuah usaha komersial baik jasa atau barang dalam perdagangan untuk mencapai tujuan yang telah ditetapkan oleh organisasi.

\section{B. Fungsi manajemen}

Menurut Sondang P. Siagian fungsi-fungsi manajemen mencakup: ${ }^{17}$

1. Perencanaan (planning) dapat didefenisikan sebagai keseluruhan proses pemikiran dan penentuan secara matang tentang hal-hal yang akan dikerjakan dimasa yang akan datang dalam rangka mencapai tujuan yang telah ditetapkan.

2. Pengorganisasian (Organizing) adalah keseluruhan proses pengelompokan orangorang, alat-alat, tugas-tugas, tanggung jawab dan wewenang sedemikian rupa sehingga menciptakan suatu organisasi yang dapat digerakkan sebagai suatu kesatuan dalam rangka pencapaian tujuan yang telah di tentukan.

3. Penggerakan (Motivating) dapat didefenisikan sebagai keseluruhan proses pemberian dorongan bekerja kepada para bawahan sedemikian rupa sehingga mereka mau bekerja dengan ikhlas demi tercapainya tujuan organisasi dengan efesien dan ekonomis.

4. Pengawasan (Controlling) adalah proses pengamatan pelaknsanaan seluruh kegiatan organisasi untuk menjamin agar semua pekerjaan yang sedang dilakukan berjalan sesuai dengan rencana yang telah ditentukan sebelumnya.

5. Penilaian (Evaluation) adalah fungsi organik administrasi dan manajemen yang terakhir. Defenisinya ialah proses pengukuran dan perbandingan hasil-hasil pekerjaan yang nyatanya dicapai dengan hasil-hasil yang seharusnya dicapai.

Begitu juga dengan fungsi manajemen bisnis kuliner, dalam pelaksanaan manajemen akan mampu memenuhi kelima fungsi tersebut, agar tujuan dari bisnis itu sendiri tercapai. Jika manajemen bisnis kuliner sesuai dengan apa yang telah direncanakan, maka kelima fungsi diatas akan berjalan dan menjadi sebuah alat untuk mencapai tujuan dari bisnis itu sendiri.

\section{METODE PENELITIAN}

Penelitian ini menggunakan pendekatan penelitian kualitatif, pendekatan kualitatif adalah dalam bentuk kata-kata, skema, dan gambar. ${ }^{18}$ Penelitian ini adalah library research (penelitian kepustakaan), yaitu penelitian yang dilaksanakan dengan menggunakan literatur (kepustakaan), baik berupa buku, catatan, maupun laporan hasil penelitian dari penelitian terdahulu ${ }^{19}$. Sebagaimana pemikiran M. Iqbal Hasan, studi dokumentasi adalah tehnik pengumpulan data yang tidak langsung ditujukan pada sebuah penelitian, namun melalui dokumen. Dokumen yang digunakan dapat berupa buku harian, surat pribadi, laporan, notulen rapat, catatan khusus dalam pekerjaan sosial

\footnotetext{
${ }^{17}$ Siagian Sondang P. 2008 Manajemen Sumber Daya manusia. Jakarta: Bumi Aksara. h. 30

18 Sugiyono. 2013. Metode Penelitian Kuantitatif Kualitatif dan R\&D. Bandung: Alfabeta h. 79

${ }^{19}$ M. Iqbal Hasan. 2002. Pokok-pokok Materi Metodologi Penelitian dan Aplikasinya. Bogor: Ghalia Indonesia. h. 89
} 
dan dokumen lainnya ${ }^{20}$. Jadi semua dokumentasi diposisikan setara tergantung ketersambungan dengan topik utama penelitian ini. Teknik pengumpulan data, dalam hal ini penulis akan melakukan identifikasi dari buku-buku, makalah atau artikel, majalah, jurnal, web (internet), ataupun informasi lainnya yang berhubungan dengan judul penulisan untuk mencari hal-hal atau variabel yang berupa catatan, transkip, buku, surat kabar, majalah dan sebagainya yang berkaitan dengan kajian tentang konsep pemikiran Hamka tentang perbankan Syariah. Maka dilakukan langkah-langkah sebagai berikut:

1) Mengumpulkan data-data yang ada baik melalui buku-buku, jurnal, dokumen, laporan-laporan periodic, majalah internet (web).

2) Menganalisa data-data tersebut sehingga peneliti bisa menyimpulkan tentang masalah yang dikaji.

Dalam penelitian ini setelah dilakukan pengumpulan data, maka data tersebut dianalisis untuk mendapatkan kesimpulan, bentuk teknik dalam teknik analisis deskriptif. Metode analisis deskriptif yaitu usaha untuk mengumpulkan dan menyususn suatu data, kemudian dilakukan analisis terhadap data tersebut ${ }^{21}$. Analisis deskriptif yakni data yang dikumpulkan adalah berupa kata-kata, gambar dan bukan angka-angka. Hal ini disebabkan oleh adanya penerapan metode kualitatif. Selain itu, semua yang dikumpulkan berkemungkinan menjadi kunci terhadap apa yang sudah diteliti. Dengan demikian laporan penelitian akan berisi kutipan-kutipan data dan pengolahan data untuk memberi gambaran penyajian laporan tersebut. Tujuan dari penggunaan penelitian kepustakaan dan jenis penelitian kualitatif adalah untuk memberikan wawasan dan pemahaman tentang penggunaan etika bisnis Islam dalam manajemen bisnis kuliner. Jenis data yang digunakan dalam penelitian ini adalah data sekunder. Data yang diperoleh dari data sekunder adalah dokumen-dokumen pemerintah, jurnal penelitian, buku dan artikel yang berkaitan dengan etika bisnis Islam.

\section{HASIL DAN PEMBAHASAN}

Sesuai dengan tujuan diciptakannya manusia yakni untuk beribadah kepada Allah dengan mentaati segala perintahnya dan menjauhi larangannya, maka setiap aktivitas manusia tidak boleh terlepas dari syariat Agama. Begitu juga dengan kegiatan pemenuhan kebutuhan yang dilakukan, salah satunya dengan berdagang atau bisnis. Bisnis yang merupakan salah satu kegiatan produksi dimana nantinya akan mendapatkan keuntungan yang digunakan sebagai kebutuhan hidup seseorang harus memiliki tujuan yang tidak hanya sebagai pemenuhan kebutuhan seseorang di dunia saja namun juga bisa sebagai pemenuhan kehidupan setelah kematian. Oleh karena itu perlu diperhatikan

${ }^{20}$ Ibid, h. 89

21 W. Surachman. 1990. Pengantar Penelitian Ilmiah. Bandung: Tarsita. h. 25 
setiap kegiatan bisnis yang dilakukan. Pelaksanaan sebuah bisnis tidak bisa dilaksanakan begitu saja tanpa sebuah dasar dan perencanaan yang baik karena resiko yang akan dihadapi tidaklah hanya ditanggung oleh satu orang saja, namun segala unsur yang berkaitan dengan bisnis tersebut seperti pihak lain (konsumen, distributor hingga pemasok bahan-bahan produksi), keuangan perusahaan dan sumber daya yang bersangkutan seperti pegawai.

Pemilihan bidang bisnis yang tepat juga akan sangat membantu pencapaian tujuan di atas, seperti perlu diperhatikan kemampuan apa yang dimiliki, seberapa besar modal yang dimiliki, peluang bisnis apa saja saat ini yang akan berkembang dan bertahan cukup lama. Bisnis yang paling memungkinkan dilakukan oleh setiap orang adalah bisnis kuliner. Bisnis kuliner sendiri memiliki peluang yang cukup besar seperti makanan akan selalu dibutuhkan oleh setiap orang, perputaran keuangan bisnis kuliner ini sangat cepat sehingga keuntungan yang didapatkan dapat langsung dinikmati dan dpat diputar lagi keesokan harinya, memiliki target pasar yang luas dari anak-anak hingga dewasa, modal yang dibutuhkan tidak terlalu besar, terdapat banyak inovasi yang bisa dilakukan dan bisnis kuliner juga bisa dapat dilakukan dimana saja saat ini, bisa dirumah dengan penjualan online, outlet ataupun memasarkannya secara langsung ke pelanggan. Keunggulan bisnis kuliner ini menjadikan bisnis tersebut berkembang pesat. Dari data dari Badan Ekonomi Kreatif (Bekraf) Republik Indonesia mencatat, subsektor kuliner berkontribusi 41,4 persen dari total kontribusi perekonomian kreatif Rp 922 triliun pada 2016. Jumlah tersebut merupakan yang paling tinggi dibandingkan 16 subsektor lain di Bekraf RI. Deputi Riset, Edukasi dan Pengembangan Bekraf RI AR Boy Berawi menyatakan bahwa kuliner merupakan salah satu penopang di industri kreatif. Dari unit 8,2 juta unit industri kreatif, 68 persen bergerak di industri kuliner.

Perkembangan yang baik ini haruslah diiringi dengan pengelolaan yang baik pula, sehingga peningkatan perkembangan bisnis kuliner tidak hanya dinikmati oleh pelaku bisnis saja namun juga semua orang. Islam memberikan sebuah konsep yang akan mampu meningkatkan pengembangan bisnis kuliner ini, yaitu etika bisnis Islam. Pengelolaan bisnis kuliner yang dikelola dengan prinsip-prinsip etika bisnis akan mampu menjadikan bisnis tersebut jauh lebih berkembang.

Konosuke Matsushita pemilik perusahaan listrik yang sudah berdiri sejak tahun 1932 menyatakan bahwa filosofi bisnisnya yang ditekankan pada karyawannya adalah pembentukan budaya dalam perusahaan, dimana bisnisnya tidak semata-mata mencari keuntungan untuk karyawan, toko-toko atau pabrik-pabrik yang bersangkutan namun juga untuk membantu masyarakat agar terbebas dari kemiskinan. Tujuh prinsip yang dimiliki perusahaan tersebut yaitu 1) Melakukan hal yang terbaik dalam pelayanan industry; 2) Menjunjung tinggi kejujuran dan keadilan; 3) Semangat dalam keselarasan dan kerjasama; 4) Semangat berjuang untuk kemajuan 5) Semangat dalam kesopanan dan 
fleksibilitas; 6) Mentaati hukum alam yang berlaku dengan menjaga lingkungan; 7) Bersyukur atas apa yang telah didapatkan. ${ }^{22}$

Ketujuh prinsip tersebut tidak ada yang bertentangan dengan prinsip-prinsip etika bisnis Islam. Hal yang membedakan dengan prinsip etika bisnis Islam adalah tujuan dan niat kegiatan bisnis yang dilakukan adalah karena merupakan sebuah bentuk pemenuhan kewajiban sebagai seorang hamba Allah. Bagi seorang muslim seluruh kegiatan yang dilakukan di dunia merupakan bentuk ibadah kepada Allah karena setiap rinci kegiatan akan dipertanggungjawabkan. Hal ini juga telah dituliskan dalam Muatasim Ismaeel bahwa etika bisnis Islam berasal dari Tuhan yakni melalui Al Quran dan Al Hadist. ${ }^{23}$ Oleh karena itu formulasi yang dibentuk dari Tuhan tidaklah mungkin merupakan hal yang buruk. Menurut Gillian Rice prinsip-prinsip etika binis Islam yaitu: 1) Tauhid, 2) Ibadah, 3) Amanah, 4) Hikmah, 5) Adil, 6) Ihsan, 7) Tolong menolong, 8) Halalan Thayyiban dan 9) Musyawarah. ${ }^{24}$

Fungsi manajemen sendiri tidak akan pernah lepas dengan yang namanya etika, penerpana etika Islam dengan maksimal disetiap fungsi manajemen akan membantu pencapaian tujuan perusahaan. Berikut penerapan etika bisnis Islam dalam bidang manajemen dan fungsi-fungsi manajemen binsis kuliner.

Tabel 1. Penerapan prinsip etika bisnis Islam pada Manajemen Bisnis Kuliner

\begin{tabular}{|c|l|}
\hline $\begin{array}{c}\text { Prinsip Etika } \\
\text { Bisnis Islam }\end{array}$ & \multicolumn{1}{|c|}{ Manajemen Bisnis Kuliner } \\
\hline Tauhid & $\begin{array}{l}\text { Dalam penerapan kelima fungsi manajemen bisnis kuliner baik } \\
\text { dalam bidang manajemen produksi, manajemen keuangan, } \\
\text { manajemen operasional, manajemen sumber daya manusia hingga } \\
\text { manajemen pemasarannya harus dilandaskan kepada yang } \\
\text { namanya tauhid. Ketika seluruh kegiatan bisnis kuliner dari awal } \\
\text { sudah atas dasar Tauhid maka segala sesuatu yang telah ditetapkan } \\
\text { tidak akan dilanggar. }\end{array}$ \\
\hline
\end{tabular}

22 Tanri abeng. 1997. Business Ethics in Islamic Context: Perspectives of a Muslim Business Leader. Business Ethics Quartely Vol 7 (3). h. 47-54

${ }^{23}$ Ismaeel, Muatasim \& Blaim, Khatarina. (2012). Toward Apllied Islamic Business Ethics: Responsible Halal Business. The Journal of Management Development. Emerald Group Publishing Limited. pp. 278-288

${ }^{24}$ Gillian Rice. (1998). Islamic Ethics and The Implications for Business. Journal of Business Ethics. Spinger Science \& Business Media. pp. 345-358 


\begin{tabular}{|c|c|}
\hline Ibadah & $\begin{array}{l}\text { Dalam penerapan kelima fungsi manajemen bisnis kuliner baik } \\
\text { dalam bidang manajemen produksi, manajemen keuangan, } \\
\text { manajemen operasional, manajemen sumber daya manusia hingga } \\
\text { manajemen pemasarannya merupakan bentuk pemenuhan } \\
\text { kewajiban kepada Allah Subhanahu Wa Ta'ala karena hasil yang } \\
\text { diharapkan adalah bukan untuk dunia saja namun juga di akhirat. }\end{array}$ \\
\hline Amanah & $\begin{array}{l}\text { Seluruh pihak yang terlibat dalam kegiatan bisnis kuliner harus } \\
\text { amanah dalam menjalani tugasnya seperti selalu menjaga kualitas } \\
\text { produk makanannya sesuai dengan apa yang telah dijanjikan } \\
\text { kepada konsumen } \\
\text { Tidak menipu dan selalu jujur baik dalam segala aktivitas di setiap } \\
\text { bidang manajemen. } \\
\text { Sumber daya alam yang digunakan seperti dalam produksi produk } \\
\text { harus diperhitungkan dengan matang agar tidak terbuang, karena } \\
\text { dalam bisnis kuliner daya tahan produknya pasti terbatas. } \\
\text { Manajemen yang baik mengenai banyaknya prouksi yang akan } \\
\text { ditawarkan kepada konsumen akan membantu mengurangi } \\
\text { tingginya makanan yang terbuang yang berdampak pada kerugian } \\
\text { perusahaan. } \\
\text { Membayar upah karyawan maupun hutang-hutang atau janji jani } \\
\text { yang dimiliki perusahaan kepada pihak lain sesuai dengan yang } \\
\text { telah diperjanjikan. }\end{array}$ \\
\hline Hikmah & $\begin{array}{l}\text { Apapun hasil yang didapatkan oleh perusahaan harus selalu } \\
\text { disyukuri. } \\
\text { Kejadian apapun yang terjadi juga harus disyukuri karena setiap } \\
\text { apapun yang terjadi adalah sebuah ujian yang aka nada nilainya di } \\
\text { hadapan Allah Subhanahu Wa Ta'ala ketika manusia terus bersabar } \\
\text { dan bersyukur. }\end{array}$ \\
\hline Adil & $\begin{array}{l}\text { Tidak memonopoli bisnis. } \\
\text { Tidak menimbun barang seperti misal penimpbunan bahan makan } \\
\text { yang sedang langka dipasaran. } \\
\text { Bisnis Kuliner harus dilakukan dengan sukarela tidak ada } \\
\text { pemaksaan anatara pihak-pihak yang terlibat baik rekan bisnis } \\
\text { maupun karyawan hingga konsumen yang akan membeli produk. } \\
\text { Menjunjung tinggi nilai-nilai keseimbangan antara ekonomi sosial. }\end{array}$ \\
\hline
\end{tabular}




\begin{tabular}{|c|c|}
\hline & $\begin{array}{l}\text { Mengantisipasi kerusakan-kerusakan yang akan terjadi ketika } \\
\text { dalam kegiatanproduksi. }\end{array}$ \\
\hline Ihsan & $\begin{array}{l}\text { Dilarang melakukan dengan proses kebatilan karena dalam } \\
\text { berkegiatan binsis akan selalu diawasi oleh allah. }\end{array}$ \\
\hline $\begin{array}{l}\text { Tolong } \\
\text { Menolong }\end{array}$ & $\begin{array}{l}\text { Tujuan dari bisnis kuliner semata-mata bukan untuk memperoleh } \\
\text { keuntungan semata, tapi bagaiamana. } \\
\text { Dalam berpromosi tidak boleh menjelekkan bisnis orang lain } \\
\text { danbisa kolaborasi saling bantu. } \\
\text { Memiliki fungsi sosial yakni zakat dan sedekah, menolong dan } \\
\text { memberi manfaat kepada orang lain }\end{array}$ \\
\hline $\begin{array}{l}\text { Halalan } \\
\text { Tayyiban }\end{array}$ & $\begin{array}{l}\text { Segala unsur yang digunakan untuk memproduksi sharus halal dan } \\
\text { tayyib seperti: } \\
\text { Menggunakan bahan yang jelas kehalalan dan baik, tidak } \\
\text { menggunakan modal yang berunsur riba. } \\
\text { Mekaninsme penjualannya tidak ada maysir seperti } \\
\text { promosi-promosi yang digunakan tidak boleh serupa dengan } \\
\text { perjudian. } \\
\text { Produk yang dijual harus jelas, mekaninsme pembayarannya, } \\
\text { harganya tidak ada yang disembunyikan atau tidak jelas. } \\
\text { Dalam jurnal berjudul Quality assurance and halal control } \\
\text { poin yang diterbitkan oleh emerald dan ditulis oleh Jan mei soon } \\
\text { dan An nee luau dan Mohd Hafiz dikatakan bahwa menjaga kualitas } \\
\text { dan kehalalan produk makanan untuk industry sangat efektif } \\
\text { meningkatkan penjualan produk karena akan meningkatkan } \\
\text { kepercayaan konsumen dalam membelinya. }\end{array}$ \\
\hline Musyawarah & $\begin{array}{l}\text { Data setiap keputusan tidak dilakukan sepihak namun di diskusikan } \\
\text { bersama seperti pemutusan kontrak kerjasama baik dengan relasi } \\
\text { bisnis maupun karyawan. } \\
\text { Setiap masalah yang terjadi juga harus dimusyawarahkan dengan } \\
\text { pihak-pihak yang memeliki kewenangan, tidak ada keputusan } \\
\text { sepihak dalam sebuah kesepakatan yang sudah diputuskan } \\
\text { bersama. }\end{array}$ \\
\hline
\end{tabular}




\section{KESIMPULAN}

Etika bisnis Islam tidak pernah bisa dilepaskan dalam kegiatan bisnis, begitu juga dengan bisnis kuliner. Prinsip-prinsip etika bisnis Islam akan mampu membantu manajemen bisnis kuliner lebih terarah dan memiliki nilai yang jelas baik di dunia maupun di akhirat. Prinsip-prinsip tersebut adalah 1) Tauhid, 2) Ibadah, 3) Amanah, 4) Hikmah, 5) Adil, 6) Ihsan, 7) Tolong menolong, 8) Halalan Thayyiban dan 9) Musyawarah. Karena kegiatan binsis bukan hanya untuk memperoleh keuntungan tapi untuk menjalankan perintah Allah dan mampu dihitung sebagai bentuk ibadah kepada Allah Subhanahu Wa Ta'ala. Penerapan etika bisnis Islam dalam manajemen bisnis kuliner akan berdampak pada kesejahteraan dan keseimbangan bersama kepada pihak-pihak yang terlibat dalam bisnis maupun yang tidak terlibat atau masyarakat umum.

\section{DAFTAR PUSTAKA}

Sugiyono. 2013. Metode Penelitian Kuantitatif Kualitatif dan R\&D. Bandung: Alfabeta h. 79 M. Iqbal Hasan. 2002. Pokok-pokok Materi Metodologi Penelitian dan Aplikasinya. Bogor: Ghalia Indonesia. h. 89

W. Surachman. 1990. Pengantar Penelitian Ilmiah. Bandung: Tarsita. h. 25

Buchari Alma dan Donni junni Priansa. 2009. Manajemen Bisnis Syariah. Bandung: Alfabeta. h. 95

Departemen Pendidikan Nasional. 2008. Kamus Besar Bahasa Indonesia, Jakarta: Pusat Bahasa. h. 105

Faisal Badroen. 2006. Etika Bisnis dalam Islam. Jakarta: Kencana, Cetakan ke-2. h. 30

Arifin Jonan. 2009. Etika Bisnis Islam. Semarang: Wali Songo Press. h. 75

Jonsson, P.O. 2011. On Utilitarianism vs virtue ethics as foundations of economic choice theory. Humanocomics. Vol 27 No. 1, h. 24-40.

Abdul Aziz. 2013. Etika Bisnis Perspektif Islam. Bandung: Alfabeta. h. 56

Ahmad Mustaq. 2001. Etika Bisnis dalam Islam. Jakarta: Pustaka Al Kautsar. h. 80

Aris Baidowi. 2011. Etika Bisnis Perspektif Islam. Jurnal Hukum Islam. Volume 9 Nomor 3. h. 1829

Afzalur Rahman. 1995. Doktrin ekonomi Islam jilid I. Yogyakarta: Dana Bhakti Wakaf

Norva Dewi. 2015. Bisnis Dalam Perspektif Islam (Telaah Konsep, prinsip dan Landasan Normatif). Al Tijary, Vol. 01 No. 01

Muslich. 2010. Etika Bisnis Islami. Yogyakarta: Ekonisia Fakultas Ekonomi UII

Undang Ahmad Kamaludin dan Muhammad Alfan. 2010. Etika Manajemen Islam. Jakarta: Pustaka Setia. h. 27

Agus Sabardi. tt. Manajemen Pengantar. Edisi Revisi, Yogyakarta, UPP AMP YKN. h. 5 
Ek. Mochtar Effendy. 1986. Manajemen: Suatu Pendekatan Berdasarkan Ajaran Islam. Jakarta: Bharata Karya Aksara.

T.R.R Kamus Bebar Bahasa Indonesia, Op. cit., h. 105

Ronald J ebert dan Ricky W. Griffin. 2006. Bisnis. Alih Bahasa Rd. Soemarnagara. Jakarta: Erlangga. h. 4

Siagian Sondang P. 2008 Manajemen Sumber Daya manusia. Jakarta: Bumi Aksara. h. 30

Tanri abeng. 1997. Business Ethics in Islamic Context: Perspectives of a Muslim Business Leader. Business Ethics Quartely Vol 7 (3). h. 47-54

Ismaeel, Muatasim \& Blaim, Khatarina. (2012). Toward Apllied Islamic Business Ethics: Responsible Halal Business. The Journal of Management Development. Emerald Group Publishing Limited. pp. 278-288.

Gillian Rice. (1998). Islamic Ethics and The Implications for Business. Journal of Business Ethics. Spinger Science \& Business Media. pp. 345-358 